\title{
Evaluation of genotoxicity using the micronucleus assay and nuclear abnormalities in the tropical sea fish Bathygobius soporator (Valenciennes, 1837) (Teleostei, Gobiidae)
}

\author{
Toni P. Galindo and Lília M. Moreira \\ Departamento de Biologia Geral, Instituto de Biologia, Universidade Federal da Bahia.
}

\begin{abstract}
The micronucleus and nuclear abnormalities assays have been used increasingly to evaluate genotoxicity of many compounds in polluted aquatic ecossystems. The aim of this study is to verify the efficiency of the micronucleus assay and nuclear abnormality assay in field and laboratory work, when using erythrocytes of the tropical marine fish Bathygobius soporator as genotoxicity biomarkers. Gill peripheral blood samples were obtained from specimens of Bathygobius soporator. In order to investigate the frequencies of micronuclei and to assess the sensitivity of species, the results were compared with samples taken at the reference site and maintained in the laboratory, and fish treated with cyclophosphamide. The micronucleus assay was efficient in demonstrating field pollution and reproducing results in the labotatory. There were significant higher frequencies of micronuclei in two sites subject to discharge of urban and industrial effluents. The nuclear abnormality assay did not appear to be an efficient tool for genotoxicity evaluation when compared with field samples taken at a reference site in laboratory, with a positive control.
\end{abstract}

Key words: micronucleus assay, nuclear abnormality assay, genotoxicity, frillfin goby, Bathygobius soporator.

Received: August 12, 2008; Accepted: January 20, 2009.

Most of the world's population has chosen to settle in coastal areas, a choice which has severely impacted these regions in terms of anthropogenic activities, such as urban construction and industrial and domestic effluents. One of the gravest problems of overpopulation, both worldwide and in Brazil, is the lack of efficient sewage-treatment systems.

Historically, the population of the city of Salvador, Bahia State, has always discharged untreated domestic and industrial waste into the coastal area (Souza Santos et al., 2000 ). In the year 1995 , only $26 \%$ of the population was benefited by adequate basic sanitary instalations, hence effluent spillings are still common in some places, mainly so during the rainy season.

Studies in the Todos os Santos Bay, where there are some Salvador city beaches, suggested contamination with poisonous and genotoxicant substances such as trace metal, polycyclic aromatic hydrocarbons and polycyclic aliphatic hydrocarbons (Tavares et al., 1988; Hatje et al., 2006). Nowadays, effluents from 29 industies drain into the bay, which, together with urban and port ativities, are responsible for considerable pollution problems (Venturini et al., 2004).

Send correspondence to Toni Pablo Galindo. Departamento de Biologia Geral, Instituto de Biologia, Universidade Federal da Bahia, 40170-115 Salvador, BA, Brazil. E-mail: pablimgalindo@ hotmail.com.
Among the various mutagen tests used for bio-monitoring contaminated environments, e.g. the comet assay (Buschini et al., 2004), nuclear aberrations (Arkhipchuk and Garanko, 2005), alterations in erythrocytes (Ateeq et al., 2002) and cromosomal aberrations (Ferraro et al., 2004), the micronuclei assay (MN) is relatively simple, reliable and sensitive, and has been used to evaluate the effects of mutagen compounds in many different environments (Al-Sabti and Metcalfe, 1995). Moreover, the micronucleus is composed either of small chromatin fragments which arise as a result of chromosome breaks after clastogenic action, or of whole chromosomes that do not migrate during anaphase as a result of aneugenic affects (Çavas and Ergene-Gözükara, 2003).

Fish have been successfully used in cytogenetic analysis, as they are easy to handle and keep in the laboratory, besides providing a relatively low-cost method (Hayashi et al., 1997). The use of fish erythrocytes allows for quick results with little suffering on the part of the organisms used in bio-monitoring (Minissi et al., 1995). This test enables detecting clastogenic (that break chromosomes) and aneugenic agents (that induce aneuplody or abnormal chromosomal segregation), and has been validated in in vivo and in vitro experiments (Al-Sabti and Metcalfe, 1995), with a great number of substances being tested in several different organisms, such as mollusks, plants, amphibians, 
reptiles, birds and mammals (Zúñiga-González et al., 2000; Venier and Zampieron, 2005).

Although several studies have been done with different species of freshwater fish as biomarkers of genotoxicity in vitro (Al-Sabti and Metcalfe, 1995; Ateeq et al., 2002) and also in polluted natural environments (Minissi et al., 1995; Hayashi et al., 1997), studies with tropical native species are just beginning. In Brazil there are few laboratory studies that have been done with micronuclei in tropical freshwater fish (Grisolia and Cordeiro, 2000; Grisolia, 2002; Grisolia et al., 2005).

Over recent years, several studies have described the presence of nuclear abnormalities (NA), other than micronuclei, in fish cells exposed to genotoxic substances (Çavas and Ergene-Gözükara, 2005). In general, these abnormalities are considered to be indicators of genotoxic damage, and therefore they may complement micronucleus scoring in routine genotoxicity surveys.

The frillfin goby (Bathygobius soporator Valenciennes, 1837) is a small teleost from the Gobiidae family, that lives in tidal pools in coastal regions and oceanic islands on both sides of the Atlantic (Lima et al., 2005). A notable adaptation to the benthic way of life is the development of a sucker formed by uniting the pelvic fins so as to enable it to cling to a substratum (Akihito et al., 2000), and feed on benthic invertebrates, eggs and zooplankton. They live in environments with enormous variations in salinity, oxygen content, turbidity and temperature (Rantin et al., 1998). The species $B$. soporator was selected for the present study, due to its sensitivity, wide distribution and abundance in rocky tidal pools.

The aim of this study is to verify the efficiency of the micronucleus and nuclear abnormalities assays, both in the field and laboratory, with erythrocytes of the tropical marine fish Bathygobius soporator, when these are used as biomarkers of genotoxicity.

Ten specimens of $B$. soporator were collected at Stella Mares in January, 2006 and kept in an aquarium (72 L, distilled water and aquarium marine salt), at a constant temperature $\left(30 \pm 3{ }^{\circ} \mathrm{C}\right)$ and salinity of $30 \%$ o, and fed with commercial fish food for 90 days. After this period, the first blood samples were taken and slides prepared for analysis of erythrocyte frequency, with micronuclei as a negative control. After fifty-four days, the fish were weighed and measured (average weight $7.47 \mathrm{~g}$ and length $8.22 \mathrm{~cm}$ ), and then submitted to an intra-peritoneal injection of cyclophosphamide (Merck) in a saline solution (4\%) with a concentration weight of $40 \mathrm{mg} / \mathrm{kg}$. Blood was collected after five days, when slides were prepared and analyzed for positive control.

Ten specimens of $B$. soporator were randomly collected at Stella Mares Beach ( $12^{\circ} 57^{\prime}$ 05” S; 38 20'

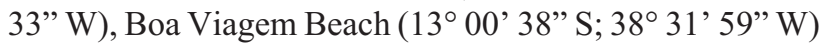
and Penha Beach (12 54' 43” S; 38 29'38” W), during March, May, August and November, 2005.
Besides the average length of the fish $(7.22 \mathrm{~cm})$, temperature, salinity and $\mathrm{pH}$ were measured in three replicates. Erythrocyte smears were obtained with heparinized syringes by puncturing the gills on previously washed microscopic slides. The fish remained unharmed and were soon returned to their natural habitat. The slides were air-dried for $24 \mathrm{~h}$, fixed in a 70\% methanol solution for $7 \mathrm{~min}$ and then dried a further $24 \mathrm{~h}$. Shortly after, they were stained with Giemsa (4\%) for 15 min. 3.000 intact erythrocytes were counted from each fish. Only cells that were clearly visible and isolated under a Zeiss microscope with amplification of $1000 \mathrm{X}$, were counted. Cells with more than four micronuclei were discarded so as to exclude apoptotic phenomena (Bolognesi et al., 2006). Nuclear abnormalities were manifest as changes in the normal elliptic shape of nuclei (Ferraro et al., 2004). For a detailed description on nuclear abnormalities see Ayllón and Garcia-Vazquez (2000), Çavas and Ergene-Gözükara (2003) and Çavas et al. (2005). Micronuclei were considered as small inclusions of nuclear material inside erythrocytic cytoplasm. Criteria for identification were a round or oval shape with a flat and well-defined outline, coloration similar to that of the main nucleus and a size from $1 / 3$ to $1 / 20$ in relation to that of the main nucleus (Al-Sabti and Metcalfe, 1995).

Data were tested for normality via the KolmogorovSmirnov test and the Bartlett test before all statistical analyses, in order to check variance homogeneity. Micronucleus frequency presented normal distribution and homogeneous variances, whereupon a one way ANOVA was performed, followed by an a posteriori Dunnett test. The frequency of nuclear abnormalities did not present homogeneous variances. Neverthless, a non-parametric Kruskall-Wallis test was done, followed by the Dunn multiple comparison test with SPSS 11.0 for Windows. The initial level of significance $(\alpha)$ was 0.1 to compensate for the increased likelihood of a type 2 error, and a Bonferroni correction was applied, this resulting in alfa 0.025 .

The results show the average frequencies of micronuclei and nuclear abnormalities in the three sites during four seasons of the year 2005 (Table 1). The frequency of micronuclei was significantly higher than in the negative control at Boa Viagem and Penha in March, May and August. Stella Mares showed a low frequency of miconuclei in comparison to the other two sampling sites, with lower frequencies in November (precipitation of $70 \mathrm{~mm}$ ), intermediate in the months of May $(200 \mathrm{~mm})$ and August $(120 \mathrm{~mm})$ and higher in March $(350 \mathrm{~mm})$. Boa Viagem presented the highest frequency of miconuclei (Figure 1). There was a significant difference between frequency of miconuclei among the negative and positive controls. However, this pattern was not observed in the frequency of nuclear abnormalities among the two control groups in spite of it being higher in the positive control group. The nuclear abnormalities in the negative control group were higher than those in the other three sites, in all the months, except in Boa 
Table 1 - Average frequency of micronucleus and nuclear abnormalities in B. soporator for 1000/cells during four months in 2005 at three sites in Salvador, Bahia, Brazil.

\begin{tabular}{lccc}
\hline Month & Site & MN \pm SD & NA \pm SD \\
\hline Negative control & & $2.23 \pm 1.79$ & $54.50 \pm 14.00$ \\
Positive control & & $6.40 \pm 2.84^{* *}$ & $68.33 \pm 24.03$ \\
\hline March & Stella Mares & $6.63 \pm 4.18$ & $14.63 \pm 7.82^{* * *}$ \\
& Boa Viagem & $17.47 \pm 7.43^{* * *}$ & $29.28 \pm 13.06^{* * *}$ \\
& Penha & $15.53 \pm 7.07^{* * *}$ & $20.60 \pm 9.47^{* *}$ \\
\hline May & Stella Mares & $2.70 \pm 1.91$ & $25.37 \pm 10.61^{* * *}$ \\
& Boa Viagem & $6.83 \pm 2.90^{* *}$ & $39.50 \pm 11.21$ \\
& Penha & $7.10 \pm 2.91^{* * *}$ & $33.77 \pm 13.46^{*}$ \\
\hline August & Stella Mares & $3.47 \pm 2.64$ & $25.80 \pm 6.98^{* * *}$ \\
& Boa Viagem & $7.43 \pm 2.43^{* * *}$ & $40.73 \pm 16.49$ \\
& Penha & $4.70 \pm 2.00$ & $27.80 \pm 5.60^{* * *}$ \\
\hline November & Stella Mares & $1.20 \pm 0.99$ & $32.70 \pm 11.00^{*}$ \\
& Boa Viagem & $3.50 \pm 1.28$ & $61.27 \pm 12.62$ \\
& Penha & $2.87 \pm 0.94$ & $40.27 \pm 14.71$ \\
\hline
\end{tabular}

MN: micronucleus; NA: nuclear abnormalities; S.D.: standard deviation. Treatments compared to the negative control by the test of multiple comparisons. $(\alpha=0.025) *$ Significantly $\mathrm{p}<0.025$. **Very Significantly $\mathrm{p}<0.01 * * *$ Extremely Significantly $\mathrm{p}<0.001$.
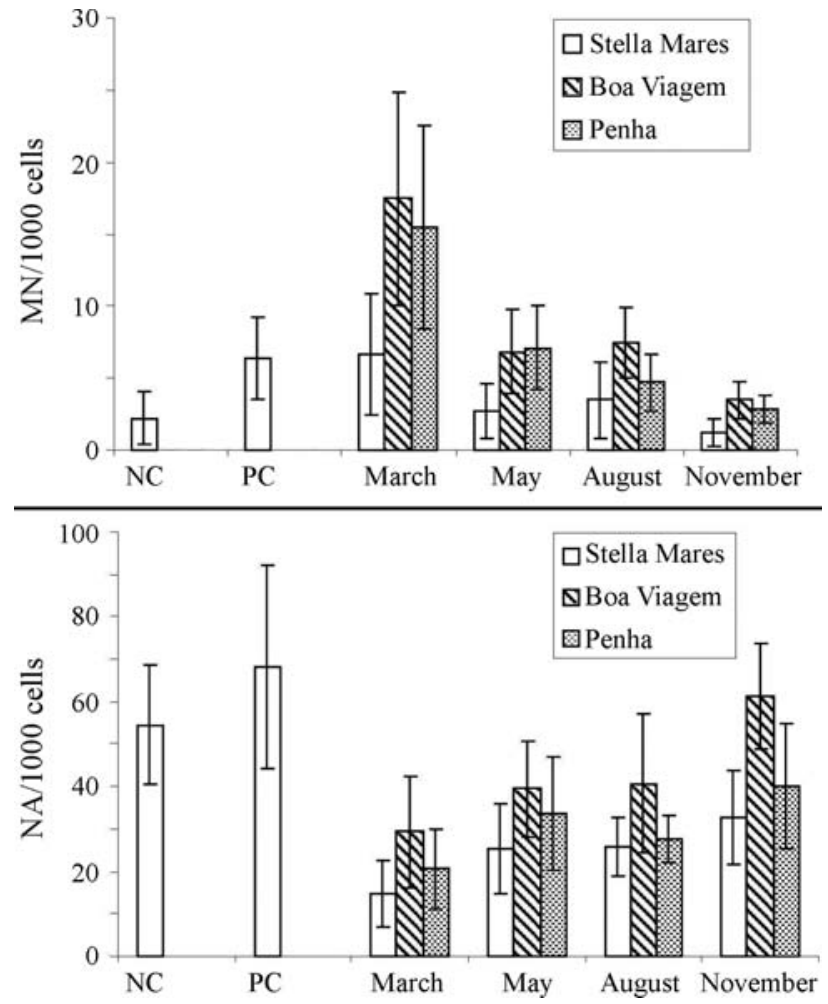

Figure 1 - Precipitation during four months of 2005 and mean frequency of micronucleated erythrocytes and nuclear abnormalities in B. soporator at three sites in and, Salvador-Bahia, Brazil. NC: negative control; NP: positive control; Prec. $\mathrm{mm}$ /months: precipitation $\mathrm{mm} /$ months. MN: micronucleus; NA: nuclear abnormalities.

Viagem for November (Table 1). Over the sampling period, temperature varied between $23^{\circ} \mathrm{C}$ (August in Penha Beach) and $40{ }^{\circ} \mathrm{C}$ (March in Stella Mares Beach). The $\mathrm{pH}$ varied between 7.49 and 8.94 in all sites. Salinity varied between 14 and $36 \%$.

The results of this study confirm the usefulness of the erythrocyte micronucleus as a powerful monitoring tool for detecting genotoxic agents in a coastal environment. Micronuclei frequencies proved to be very reliable for testing genotoxicity in studies in situ and in vitro, as it was possible to compare results obtained in the field with those from the laboratory. The present study suggests that nuclear abnormalities are not good indicators for genotoxicity evaluation in field studies, since their frequencies were higher in the negative and positive control groups in relation to the sites and months of collection.. It is worth emphasizing that the mechanisms of formation of these nuclear abnormalities are not yet fully understood (Çavas and Ergene-Gözükara, 2003). The results of studies with nuclear abnormalities demonstrate their effectiveness as genotoxicity markers mainly in fresh water fishes and in the laboratory under controlled conditions (Ayllón and Garcia-Vazquez, 2000; Çavas and Ergene-Gözükara, 2005), although it is also necessary to test these parameters in field studies. The need for controls is emphasized in the laboratory for comparison with field studies as a means of reaching more reliable conclusions, since it is through this that the effectiveness of the micronucleus test and not of the nuclear abnormality assay was corroborated. Uncertainties in the extrapolation of laboratory data to natural ecosystems will always exist, as many physical, chemical and biological factors are wholly integrated into the aquatic environment, thereby being very difficult to reproduce. Furthermore, standard laboratory conditions are very different from those in nature (Araújo et al., 2006). Several studies have demon- 
strated increases in micronuclei frequency in species of marine fish in polluted areas, and their use as genotoxicity markers in accordance with the present study (Al-Sabti and Metcalfe, 1995; Hayashi et al., 1998), and also in the laboratory (Ateeq et al., 2002; Teles et al., 2003; Buschini et al., 2004; Çavas et al., 2005). Other authors have demonstrated the success of using the micronucleus test in the evaluation of environmental quality, by using several freshwater fish (Minissi et al., 1996; Hayashi et al., 1998).

A clear seasonal variation was observed in the frequency of micronuclei and nuclear abnormality. Precipitation seems to be a relevant variable in relation to the increase in micronuclei frequency. Micronuclei frequency in the least rainy month (November, $70 \mathrm{~mm}$ ) was lower than in the rainiest (March, $350 \mathrm{~mm}$ ) in all the three reference locations. Nuclear abnormality frequency was the lowest in March and the highest in November in all the sites. In the rainier months, surface-water runoff carries chemical drainage into streams or rivers and finally to beaches. Urban storm-water runoff is now recognized as a major source of pollutants in receiving waters, and a number of recent investigations have traced oil and grease, nutrients (Kayhanian et al., 2007), total hydrocarbons, PHAs and heavy metals (Legret and Pagotto, 1999; Davis et al., 2000 ) in runoff waters. Additionally, large quantities of industrial and urban effluents are discharged into rivers, ponds and directly into the sea. These effluents might contain organic, inorganic and metallic substances with potential genotoxicants such as heavy metals, PHAs, PCB and pesticides (Claxton et al., 1998; White and Rasmussen, 1998).

From this study, it can be concluded that the micronucleus test as applied to the sea fish $B$. soporator showed to be very efficient in determining genotoxicity in impacted coastal areas. This fish is a sensitive species for bio-monitoring, as well as being an abundant tropical species, easily kept in the laboratory and with a wide distribution along the Brazilian coast. Hence, Sánchez-Galán et al. (2001) suggested that benthic fishes are more useful for monitoring sediment contamination. The nuclear abnormality assay did not prove to be a reliable tool for genotoxicity evaluation in field studies, when compared with negative and positive controls. Monthly rainfall constitutes a variable that seems to be associated with micronuclei frequency, seeing that there was a decrease in frequency during the less rainy months and an increase in the months with higher rainfall.

\section{Acknowledgments}

We wish to thank Dr. Eduardo Mendes, Dr. Francisco Barros, Dr. Francisco dos Santos, James Corcoran, Iago Cabanelas, the staff of the Laboratory of Amphibians and Human Genetics and Cytogenetics of the Federal University of Bahia for great help in the use of methods, as well as Dra. Gildete Lessa of the Bahia Nucleus of Oncology and the Fundação de Apoio à Pesquisa do Estado da Bahia (FAPESB) for the grant provided.

\section{References}

Akihito, Iwata A, Kobayashi T, Ikeo K, Imanishi T, Ono H, Umehara Y, Hamamatsu C, Sugiyama K, Ikeda Y et al. (2000) Evolutionary aspects of gobioid fishes based upon a phylogenetic analysis of mitochondrial cytochrome $b$ genes. Gene 259:5-15.

Al-Sabti K and Metcalfe CD (1995) Fish micronuclei for assessing genotoxicity in water. Genet Toxicol 343:121-135.

Araújo CVM, Cohin-de-Pinho SJ, Santos JS, Delgado F, Santana LCS, Chastinet CBA and Silva EM (2006) In situ and laboratory bioassays using Poecilia reticulata Peters, 1859 in the biomonitoring of an acidic lake at Camaçari, BA, Brazil. Chemosphere 65:599-603.

Arkhipchuk VV and Garanko NN (2005) Using the nucleolar biomarker and the micronucleus test on in vivo fish fin cells. Ecotoxicol Environ Safety 62:42-52.

Ateeq B, Farah MA, Ali MN and Ahmad W (2002) Induction of micronuclei and erythrocyte alterations in the catfish Clarias batrachus by 2,4-dichlorophenoxyacetic acid and butachlor. Mutat Res 518:135-144.

Ayllón F and Garcia-Vazquez E (2000) Induction of micronuclei and other nuclear abnormalidades in European minnow Phoxinus phoxinus and mollie Poecilia latipinna: An assessment of the fish micronucleus test. Mutat Res 467:177-186.

Bolognesi C, Perrone E, Roggieri P, Pampanin DM and Sciutto A (2006) Assessment of micronuclei induction in peripheral erythrocytes of fish exposed to xenobiotics under controlled conditions. Aquat Toxicol 78S:S93-S98.

Buschini A, Martino A, Gustavino B, Monfrinotti M, Poli P, Rossi C, Santoro M, Dörr AJM and Rizzoni M (2004) Comet assay and micronucleus test in circulation erythrocytes of Cyprinus carpio specimes exposed in situ to lake waters treated with desinfectants for potabilization. Mutat Res 557:119-129.

Çavas T and Ergene-Gözükara S (2003) Micronuclei, nuclear lesions and interphase silver-stained nuclear organizer regions (AgNORs) as cyto-geneotoxicity indicators in Oreochromis niloticos exposed to textile mill effluent. Mutat Res 538:87-91.

Çavas T and Ergene-Gözükara S (2005) Induction of micronuclei and nuclear abnormalities in Oreochromis niloticos following exposure to petroleum refinery and chromium processing plant effluents. Aquat Toxicol 74:264-271.

Çavas T, Garanko NN and Arkhipchuk VV (2005) Induction of micronuclei and binuclei in blood, gill and liver cells of fishes subchronically exposed to cadmium chlorid and copper sulphate. Food Chem Toxicol 43:569-574.

Claxton LD, Houk VS and Hughes TJ (1998) Genotoxicity of industrial wastes and effluents. Mutat Res 410:237-243.

Davis AP, Shokouhian M and Ni S (2000) Loading estimates of lead, copper, cadmiun, and zinc in urban runoff from specific sources. Chemosphere 44:997-1009.

Ferraro MVM, Fenocchio AS, Mantovani MS, Ribeiro CO and Cestari MM (2004) Mutagenic effects of tributyltin and inorganic lead ( $\mathrm{Pb}$ II) on the fish H. Malabaricus as evaluated using the comet assay and piscine micronucleus and chromosome aberration tests. Genet Mol Biol 27:103-107. 
Grisolia CKA (2002) Comparison between mouse and fish micronucleus test using cyclophosphamide, mitomycin $\mathrm{C}$ and various pesticides. Mutat Res 518:145-150.

Grisolia CK and Cordeiro CMT (2000) Variability in micronucleus induction with different mutagens applied to several species of fish. Genet Mol Biol 23:235-239.

Grisolia CK, Oliveira ABB, Bonfim H and Klautau-Guimarães N (2005) Genotoxicity evaluation of domestic sewage in a municipal waste-water treatment plant. Genet Mol Biol 28:334-338.

Hayashi M, Ueda T, Uyeno K, Wada K, Kinae N, Saotme K, Tanaka N, Takai A, Sasaki YF, Asano N et al. (1998) Development of genotoxicity assay systems that use aquatic organisms. Mutat Res 399:125-133.

Hatje V, Barros F, Figueiredo DG, Santos VLCS and Peso-Aguiar MC (2006) Trace metal contamination and benthic assemblages in Subaé estuarine system, Brazil. Mar Pollut Bull 52:982-987.

Kayhanian M, Suverkropp C, Ruby A and Tsay K (2007) Characterization and prediction of highway runoff constituent event mean concentration. J Environ Manag 85:279-295.

Legret M and Pagotto C (1999) Evaluation of pollutant loadings in the runoff waters from a major rural highway. Sci Total Environ 235:143-150.

Lima D, Freitas JEP, Araújo ME and Solé-Cava AM (2005) Genetic detection of cryptic species in the frillfin goby Bathygobius soporator. J Exp Mar Biol Ecol 302:211-223.

Minissi S, Ciccoti E and Rizzoni M (1995) Micronucleus test in erythrocytes of Barbus plebejus (Teleostei, Pisces) from two natural environments: A biossay for the in situ detection of mutagens in freshwater. Mutat Res 367:245-251.

Rantin FT, Gesser H, Kalinin AL, Guerra CDR, De Freitas JC and Driedzic WR (1998) Heart perfomance, $\mathrm{Ca}^{2+}$ regulation and energy meabolism at high temperatures in Bathygobius soporator, a tropical marine teleost. J Therm Biol 23:31-39.
Sánchez-Galán S, Linde AR, Ayllón F and Garcia-Vazquez E (2001) Induction of micronuclei in eels (Anguilla anguilla L.) by heavy metals. Ecotoxicol Environ Saf 49:139-143.

Souza Santos VLC, Raymundo CC and Tavarez T (2000) Isomers of the dodecylbenzene in marine sediments from the Todos os Santos Bay, Bahia, Brazil. Aquat Ecosyst Health Manag 3:479-484.

Tavares TM, Rocha VC, Porte VC, Barceló D and Albaigés J (1988) Application of the mussel watch concept in studies of hidrocarbons, PCBs and DDT in the Brazilian Bay of Todos os Santos (Bahia). Mar Pollut Bull 19:575-578.

Teles M, Pacheco M and Santos MA (2003) Anguilla anguilla L. Liver ethoxyresorufin O-deethylation, glutathione S-tranferase, erythrocytic nuclear abnormalities, and endocrine responses to naphthalene and $\beta$-naphthoflavone. Ecotoxicol Environ Saf 55:98-107.

Venier P and Zampieron C (2005) Evidence of genetic damage in grass gobies and mussels from the Venice lagoon. Environ Int 31:1053-1064.

Venturini N, Tommasi LA, Bicego MC and Martins CC (2004) Characterization of the benthic environment of a coastal area adjacent to an oil refinery, Todos os Santos Bay (NE-Brazil). Braz J Oceanogr 5:123-134.

White PA and Rasmussen JB (1998) The genotoxic hazards of domestic wastes in surface waters. Mutat Res 410:223-236.

Zúñiga-González G, Torres-Bugarin $\mathrm{O}$, Luna-Aguirre J, Gonzalez-Rodriguez A, Zamora-Perez A, Gomez-Meda BC, Ventura-Aguilar AJ, Ramos-Ibarra ML, Ramos-Mora A, Ortiz GG et al. (2000) Spontaneous micronuclei in peripheral blood erythrocytes from 54 animal species (mammals, reptiles and birds): Part two. Mutat Res 467:99-103.

\section{Associate Editor: Catarina S. Takahashi}

License information: This is an open-access article distributed under the terms of the Creative Commons Attribution License, which permits unrestricted use, distribution, and reproduction in any medium, provided the original work is properly cited. 